\title{
Front Matter: Volume 7754
}

, "Front Matter: Volume 7754," Proc. SPIE 7754, Metamaterials: Fundamentals and Applications III, 775401 (2 November 2010); doi: 10.1117/12.879266

SPIE Event: SPIE NanoScience + Engineering, 2010, San Diego, California, United SPIE. States 


\title{
PROCEEDINGS OF SPIE
}

\section{Metamaterials: Fundamentals and Applications III}

\author{
Allan D. Boardman \\ Nader Engheta \\ Mikhail A. Noginov \\ Nikolay I. Zheludev \\ Editors
}

1-5 August 2010

San Diego, California, United States

Sponsored and Published by

SPIE 
The papers included in this volume were part of the technical conference cited on the cover and title page. Papers were selected and subject to review by the editors and conference program committee. Some conference presentations may not be available for publication. The papers published in these proceedings reflect the work and thoughts of the authors and are published herein as submitted. The publisher is not responsible for the validity of the information or for any outcomes resulting from reliance thereon.

Please use the following format to cite material from this book:

Author(s), "Title of Paper," in Metamaterials: Fundamentals and Applications III, edited by Allan D. Boardman, Nader Engheta, Mikhail A. Noginov, Nikolay I. Zheludev, Proceedings of SPIE Vol. 7754 (SPIE, Bellingham, WA, 2010) Article CID Number.

ISSN 0277-786X

ISBN 9780819482501

Published by

SPIE

P.O. Box 10, Bellingham, Washington 98227-0010 USA

Telephone +1 3606763290 (Pacific Time) · Fax +1 3606471445

SPIE.org

Copyright (C) 2010, Society of Photo-Optical Instrumentation Engineers

Copying of material in this book for internal or personal use, or for the internal or personal use of specific clients, beyond the fair use provisions granted by the U.S. Copyright Law is authorized by SPIE subject to payment of copying fees. The Transactional Reporting Service base fee for this volume is $\$ 18.00$ per article (or portion thereof), which should be paid directly to the Copyright Clearance Center (CCC), 222 Rosewood Drive, Danvers, MA 01923. Payment may also be made electronically through CCC Online at copyright.com. Other copying for republication, resale, advertising or promotion, or any form of systematic or multiple reproduction of any material in this book is prohibited except with permission in writing from the publisher. The CCC fee code is 0277-786X/10/\$18.00.

Printed in the United States of America.

Publication of record for individual papers is online in the SPIE Digital Library.

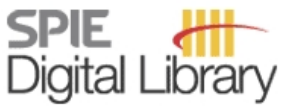

SPIEDigitalLibrary.org

Paper Numbering: Proceedings of SPIE follow an e-First publication model, with papers published first online and then in print and on CD-ROM. Papers are published as they are submitted and meet publication criteria. A unique, consistent, permanent citation identifier (CID) number is assigned to each article at the time of the first publication. Utilization of CIDs allows articles to be fully citable as soon they are published online, and connects the same identifier to all online, print, and electronic versions of the publication. SPIE uses a six-digit CID article numbering system in which:

- The first four digits correspond to the SPIE volume number.

- The last two digits indicate publication order within the volume using a Base 36 numbering system employing both numerals and letters. These two-number sets start with $00,01,02,03,04$, $05,06,07,08,09,0 A, 0 B \ldots 0 Z$, followed by 10-1Z, 20-2Z, etc.

The CID number appears on each page of the manuscript. The complete citation is used on the first page, and an abbreviated version on subsequent pages. Numbers in the index correspond to the last two digits of the six-digit CID number. 


\section{Contents}

ix Conference Committee

\section{METAMATERIALS: NONLINEAR AND ACTIVE}

775403 Active plasmonic and metamaterials and devices (Invited Paper) [7754-02]

S.-K. Kim, University of California, Los Angeles (United States); N. Sylvain, S. J. Benight, I. Kosilkin, D. H. Bale, B. H. Robinson, Univ. of Washington (United States); J. Park, University of California, Los Angeles (United States); K. Geary, HRL Labs., LLC (United States); A. K.-Y. Jen, Univ. of Washington (United States); W. H. Steier, University of Southern California (United States); H. R. Fetterman, University of California, Los Angeles (United States); P. Berini, Univ. of Ottawa (Canada); L. R. Dalton, Univ. of Washington (United States)

775405 Strongly nonlinear wave control in gyroelectric metamaterials [7754-04]

A. D. Boardman, P. Egan, R. C. Mitchell-Thomas, Univ. of Salford (United Kingdom);

Y. G. Rapoport, Univ. of Salford (United Kingdom) and Taras Shevchenko Kyiv National Univ. (Ukraine)

775409 Tunable metamaterial binary nano-particle dispersed liquid crystal cells [7754-08] R. Aylo, P. P. Banerjee, G. Nehmetallah, Univ. of Dayton (United States)

HYPERBOLIC AND 'NEAR-ZERO' METAMATERIALS

$7754 \mathrm{OE} \quad$ Strong spatial dispersion in nanostructured multilayered metal-dielectric optical metamaterials [7754-13]

A. A. Orlov, A. V. Chebykin, St. Petersburg State Univ. of Information Technologies, Mechanics and Optics (Russian Federation); P. A. Belov, St. Petersburg State Univ. of Information Technologies, Mechanics and Optics (Russian Federation) and Queen Mary, Univ. of London (United Kingdom)

7754 OG Multilayer near-IR metallo-dielectric zero index metamaterials with matched impedance [7754-15]

S. Yun, Z. H. Jiang, Q. Xu, J. A. Bossard, D. H. Werner, Z. Liu, T. S. Mayer, The Pennsylvania State Univ. (United States)

\section{LOSS AND GAIN IN METAMATERIALS}

7754 OK Harnessing the electromagnetic absorptions of metamaterials for positive applications (Invited Paper) [7754-18]

Y. Xiang, Y. Zou, H. Luo, Key Lab. for Micro/Nano Optoelectronic Devices, Hunan Univ. (China); X. Dai, Hunan Univ. (China); S. Wen, D. Fan, Key Lab. for Micro/Nano Optoelectronic Devices, Hunan Univ. (China) 
7754 OM Semiconductor plasmonic metamaterials for near-infrared and telecommunication wavelength [7754-20]

G. V. Naik, V. M. Shalaev, Purdue Univ. (United States); A. Boltasseva, Purdue Univ. (United

States) and Technical Univ. of Denmark (Denmark)

\section{PLASMONIC MATERIALS}

7754 OR Meta-acousto-optics: the interaction of light and sound in an acoustic negative index medium [7754-25]

P. P. Banerjee, Univ. of Dayton (United States)

METAMATERIALS: FUNDAMENTALS AND NOVEL TRENDS

7754 OS Physical restrictions on the Casimir force between metal-dielectric metamaterials (Invited Paper) [7754-26]

M. G. Silveirinha, Univ. of Coimbra (Portugal)

7754 OT On the nanoscale transmission of quantum angular momentum (Invited Paper) [7754-27]

D. L. Andrews, Univ. of East Anglia Norwich (United Kingdom)

7754 OV ID current driven metamaterial homogenization [7754-29]

C. Fietz, G. Shvets, The Univ. of Texas at Austin (United States)

\section{CHIRAL METAMATERIALS}

$7754 \mathrm{OZ}$ Chiral metamaterials reduce the attractive Casimir force [7754-33]

R. Zhao, Ames Lab. (United States), Iowa State Univ. (United States), and Beijing Normal Univ. (China); T. Koschny, Ames Lab. (United States), lowa State Univ. (United States), and Univ. of Crete (Greece); E. N. Economou, Univ. of Crete (Greece); C. M. Soukoulis, Ames Lab.

(United States), lowa State Univ. (United States), and Univ. of Crete (Greece)

TRANSMISSION, PROPAGATION, AND LOCALIZATION

775411 Experimental demonstration of slowing light by oscillatory mode in left-handed waveguides [7754-35]

T.-Y. Huang, T.-C. Yang, T.-J. Yen, National Tsing Hua Univ. (Taiwan)

775412 Slowing down the light by using coupled stereoscopic dielectric metamaterials [7754-36] C.-K. Chen, T.-J. Yen, National Tsing Hua Univ. (Taiwan)

775413 Light transport in 2D photonic glasses [7754-37]

D. Felbacq, CNRS, Univ. Montpellier 2 (France); K. Vynck, Univ. degli Studi di Firenze (Italy)

775414 Gain in negative-index metamaterials and slow-light waveguides (Invited Paper) [7754-92] S. Wuestner, E. I. Kirby, A. Pusch, K. L. Tsakmakidis, J. M. Hamm, O. Hess, Univ. of Surrey (United Kingdom) 
775415 Propagation of a Gaussian beam through a stack of positive and negative refractive index materials [7754-38]

A. Ghosh, P. Verma, The Univ. of Oklahoma, Tulsa (United States); P. P. Banerjee, R. Aylo, Univ. of Dayton (United States)

775418 Antenna-assisted enhanced transmission through subwavelength nanoholes [7754-41] S. Xiao, L. Peng, N. A. Mortensen, Technical Univ. of Denmark (Denmark)

775419 Optical Anderson localization in one-dimension: a non-Monte Carlo approach for continuous disorder [7754-42]

G. J. Kissel, Univ. of Southern Indiana (United States)

META-ATOMS AND THEIR INTERACTIONS

7754 1D Depth and extent of gold nanorod photothermal conversion in tissue-like phantoms that contain hemoglobin [7754-46]

N. Sharma, Lawson Health Research Institute (Canada) and Univ. of Western Ontario (Canada); A. Chamson-Reig, Lawson Health Research Institute (Canada); H. Al-Aabed, J. J. L. Carson, Lawson Health Research Institute (Canada) and Univ. of Western Ontario (Canada)

FOCUSING AND IMAGING WITH METAMATERIALS

$7754 \mathrm{lE}$ Optimal parameters of metallic nanorods arrays for subwavelength imaging (Invited Paper) [7754-47]

P. A. Belov, Queen Mary, Univ. of London (United Kingdom) and St. Petersburg State Univ. of Information Technologies, Mechanics, and Optics (Russian Federation); A. Rahman, Queen Mary, Univ. of London (United Kingdom); S. Y. Kosulnikov, St. Petersburg State Univ. of Information Technologies, Mechanics, and Optics (Russian Federation)

$7754 \mathrm{IF}$ Super-lensing effect of $\mathrm{TiO}_{2} \mathrm{NFSL}$ in the mid IR regime [7754-48]

K. Lee, Y. Jung, K. Kim, Yonsei Univ. (Korea, Republic of)

775411 Tunable subwavelength focusing with slit-groove-based metamaterials in THz [7754-51] J. Lee, K. Lee, H. Park, G. Kang, K. Kim, Yonsei Univ. (Korea, Republic of)

NEGATIVE: INDEX, PERMITTIVITY, AND REFRACTION

7754 1T Negative refractive index in doped semiconductors via electromagnetically induced mixed-parity transitions [7754-63]

A.-G. Kussow, A. Akyurtlu, Univ. of Massachusetts Lowell (United States)

$77541 \mathrm{U}$ A three-dimensional negative refractive index medium operated at multiple-angle incidences [7754-64]

T.-T. Yeh, T.-J. Yen, National Tsing Hua Univ. (Taiwan) 
7754 IV Material parameters of optical metamaterials formed by nano-fishnet structures [7754-65] I. V. Melchakova, E. A. Yankovskaya, St. Petersburg State Univ. of Information Technologies, Mechanics and Optics (Russian Federation); P. A. Belov, St. Petersburg State Univ. of Information Technologies, Mechanics and Optics (Russian Federation) and Queen Mary, Univ. of London (United Kingdom); C. R. Simovski, Helsinki Univ. of Technology (Finland)

7754 1X Characteristics of surface modes in singly negative metamaterial waveguides (Invited Paper) [7754-67]

B. Lee, Seoul National Univ. (Korea, Republic of); K.-Y. Kim, Sejong Univ. (Korea, Republic of); I.-M. Lee, J. Park, Seoul National Univ. (Korea, Republic of)

\section{TRANSFORMATION OPTICS AND CLOAKING}

$775420 \quad$ Maxwell fisheye and Eaton lenses emulated by a microdroplet (Invited Paper) [7754-71] V. N. Smolyaninova, Towson Univ. (United States); I. I. Smolyaninov, University of Maryland (United States); A. V. Kildishev, V. M. Shalaev, Purdue Univ. (United States)

\section{POSTER SESSION}

775422 Analysis of plasmon-polariton band structures of T-shaped plasmonic gratings [7754-73] M. N. Abbas, Academia Sinica (Taiwan) and National Tsing Hua Univ. (Taiwan); Y.-C. Chang, M.-H. Shih, Academia Sinica (Taiwan)

775423 A comparison of localization effects in one-dimensional disordered photonic bandgap structures [7754-74]

G. J. Kissel, C. A. McGill, Univ. of Southern Indiana (United States)

775424 General condition of transparent linearly transformed finite-embedded metamaterial slab [7754-75]

I.-M. Lee, S.-Y. Lee, Seoul National Univ. (Korea, Republic of); K.-Y. Kim, Sejong Univ. (Korea, Republic of); B. Lee, Seoul National Univ. (Korea, Republic of)

775425 Electrically tunable omnidirectional photonic bandgap in one-dimensional photonic crystal with nonlinear composite materials and metamaterials [7754-76]

Y. Xiang, S. Wen, Key Lab. for Micro/Nano Optoelectronic Devices, Hunan Univ. (China); X. Dai, Hunan Univ. (China); D. Fan, Key Lab. for Micro/Nano Optoelectronic Devices, Hunan Univ. (China)

775426 Dynamics of anomalous ultrashort pulse splitting in nonlinear metamaterials [7754-77] J. Zhang, Key Lab. for Micro/Nano Optoelectronic Devices, Hunan Univ. (China) and Hunan First Normal College (China); S. Wen, Key Lab. for Micro/Nano Optoelectronic Devices, Hunan Univ. (China)

775427 Transverse modulation instability of copropagating light beams and the bright and dark spatial solitons in nonlinear metamaterials [7754-78]

X. Dai, Hunan Univ. (China); Y. Xiang, S. Wen, D. Fan, Key Lab. for Micro/Nano

Optoelectronic Devices, Hunan Univ. (China) 
775428 Rigorous analysis of non-magnetic cloaks [7754-79]

J. Zhang, Technical Univ. of Denmark (Denmark); Y. Luo, Imperial College London

(Denmark); N. A. Mortensen, Technical Univ. of Denmark (Denmark)

7754 2A Effective electromagnetic parameters of two-dimensional dielectric photonic crystal within band gap [7754-81]

D. Song, Z. Tang, S. Wen, Key Lab. for Micro/Nano Optoelectronic Devices, Hunan Univ. (China)

$77542 \mathrm{~B} \quad$ Green's function integral equation method for propagation of electromagnetic waves in an anisotropic dielectric-magnetic slab [7754-82]

W. Shu, X. Lv, H. Luo, S. Wen, Key Lab. for Micro/Nano Optoelectronic Devices, Hunan Univ. (China)

7754 2C Study of surface electrical properties of InAIGaAs structures grown on InP substrates [7754-83]

C.-C. Chang, M.-S. Hsu, Chinese Military Academy (Taiwan); Y.-C. Wang, Nan Jeon Institute of Technology (Taiwan); W.-J. Chen, National Cheng Kung Univ. (Taiwan); J.-W. Huang,

S.-Y. Huang, B.-H. Wang, S.-H. Chen, Chinese Military Academy (Taiwan)

$775421 \quad$ A compact transmission-line metamaterial bandpass filter with ultra-wide-bandwidth for 60 GHz application [7754-89]

A.-P. Yen, T.-J. Yen, National Tsing Hua Univ. (Taiwan)

Author Index 
Downloaded From: https://www.spiedigitallibrary.org/conference-proceedings-of-spie on 26 Apr 2023

Terms of Use: https://www.spiedigitallibrary.org/terms-of-use 


\title{
Conference Committee
}

\author{
Symposium Chairs
}

David L. Andrews, University of East Anglia Norwich (United Kingdom) James G. Grote, Air Force Research Laboratory (United States)

\section{Conference Chairs}

Allan D. Boardman, University of Salford (United Kingdom) Nader Engheta, University of Pennsylvania (United States) Mikhail A. Noginov, Norfolk State University (United States) Nikolay I. Zheludev, University of Southampton (United Kingdom)

Program Committee

David L. Andrews, University of East Anglia Norwich (United Kingdom)

Koray Aydin, California Institute of Technology (United States)

Larry R. Dalton, University of Washington (United States)

Graeme Dewar, University of North Dakota (United States)

Ildar R. Gabitov, The University of Arizona (United States)

Francisco Javier García de Abajo, Consejo Superior de Investigaciones Científicas (Spain)

Satoshi Kawata, Osaka University (Japan)

Jacob B. Khurgin, The Johns Hopkins University (United States)

Yuri S. Kivshar, The Australian National University (Australia)

Joachim R. Krenn, Karl-Franzens-Universität Graz (Austria)

Akhlesh Lakhtakia, The Pennsylvania State University (United States)

Ulf Leonhardt, University of St. Andrews (United Kingdom)

Martin W. McCall, Imperial College London (United Kingdom)

Graeme Milton, The University of Utah (United States)

Herbert O. Moser, National University of Singapore (Singapore)

Martin Moskovits, API Nanotronics Corporation (United States) and

University of California, Santa Barbara (United States)

Evgenii E. Narimanov, Purdue University (United States)

Lixin Ran, Zhejiang University (China)

Andrey K. Sarychev, Institute for Theoretical and Applied

Electromagnetics (Russian Federation)

Vladimir M. Shalaev, Purdue University (United States)

Gennady Shvets, The University of Texas at Austin (United States)

Mark I. Stockman, Georgia State University (United States)

Sergei Tretyakov, Helsinki University of Technology (Finland)

Din Ping Tsai, National Taiwan University (Taiwan)

Lucio Vegni, Università degli Studi di Roma Tre (Italy) 
Session Chairs

1 Metamaterials: Nonlinear and Active

Natalia M. Litchinitser, University at Buffalo (United States)

2 Hyperbolic and 'Near-Zero' Metamaterials

Dorota Pawlak, Institute of Electronic Materials Technology (Poland)

3 Loss and Gain in Metamaterials

Allan D. Boardman, University of Salford (United Kingdom)

Mikhail A. Noginov, Norfolk State University (United States)

$4 \quad$ Plasmonic Materials

Gururaj V. Naik, Purdue University (United States)

5 Metamaterials: Fundamentals and Novel Trends

Ildar R. Gabitov, The University of Arizona (United States)

6 Chiral Metamaterials

David L. Andrews, University of East Anglia Norwich (United Kingdom)

7 Transmission, Propagation, and Localization

Koray Aydin, California Institute of Technology (United States)

8 Meta-Atoms and Their Interactions

David F. P. Pile, Nature Photonics (Japan)

$9 \quad$ Focusing and Imaging with Metamaterials

Pavel A. Belov, Queen Mary, University of London (United Kingdom)

10 Design and Fabrication of Metamaterials

Claire Bedrock, IOP Publishing, Ltd. (United Kingdom)

11 Negative: Index, Permittivity, and Refraction

Mikhail A. Noginov, Norfolk State University (United States)

12 Transformation Optics and Cloaking

Mikhail A. Noginov, Norfolk State University (United States) 